\title{
Comparative leaf anatomy of neotropical Stylogyne species (Myrsinoideae - Primulaceae)
}

Anatomia foliar comparada de espécies neotropicais de Stylogyne (Myrsinoideae - Primulaceae)

\author{
Bruna Nunes de Luna ${ }^{1,3}$, Tatiana Tavares Carrijo ${ }^{2}$, Maria de Fátima Freitas ${ }^{1}$ \& Claudia Franca Barros ${ }^{1}$
}

\begin{abstract}
Anatomical studies were performed here in order to provide diagnostic characteristics to differentiate the species Stylogyne depauperata, S. pauciflora, S. sordida and S. warmingii. Fully expanded leaves were processed by the usual techniques of optical microscopy and scanning electron microscopy. Traits common to all species were observed, such as dorsiventral mesophyll, unistratified epidermis, anisocytic stomata, druses and secretory cavities distributed throughout the mesophyll. Cuticular ornamentation, configuration of the vascular system in the petiole and shape of the secretory cavities provide diagnostic characteristics. Variance analysis proved that these characters are potentially efficient to differentiate these species.

Key words: Ardisia, secretory structures, taxonomy, Myrsinaceae.

\section{Resumo}

Estudos anatômicos foram realizados com o objetivo de buscar caracteres diagnósticos para diferenciar Stylogyne depauperata, S. pauciflora, S. sordida and S. warmingii. Folhas totalmente expandidas foram submetidas aos procedimentos usuais em microscopia óptica e eletrônica de varredura. As espécies analisadas apresentam mesofilo dorsiventral, epiderme uniestratificada, estômatos anisocíticos, idioblastos com cristais em drusas e cavidades secretoras dispersas pelo mesofilo. Caracteres diagnósticos são a ornamentação cuticular, disposição do sistema vascular no pecíolo e forma das cavidades secretoras. As análises de variância reforçam a eficiência desses caracteres para a segregação das espécies.
\end{abstract}

Palavras-chave: Ardisia, estruturas secretoras, taxonomia, Myrsinaceae.

\section{Introduction}

The Neotropical Stylogyne A.DC. comprises 18 species in Brazil (Carrijo et al. 2012) distributed in Amazon and Atlantic Rain Forests. The nine members of Atlantic Rain Forest are shrubs with leaves generally punctuated, small 4(5)-merous flowers, and brightly colored fruits (Carrijo \& Freitas 2008). The six species with 4-merous flowers seems to be a natural group, characterized by a high frequency of local endemism and low tolerance to environmental disturbance (Carrijo \& Freitas 2008, 2009; Carrijo et al. 2011). Some of these species are circumscribed by fine characters (e.g. calyx papillose, anthers opening by short or long slits) or by a set of shared features (e.g. inflorescence racemose or fasciculate, petals punctuate), which sometimes makes it difficult to distinguish related taxa from extremes of infraspecific variation. Anatomical traits proved to be a value tool to delimit taxonomically related species, to provide a consistent foundation for phylogenetic studies, and other ecological applications of species from the Atlantic Rain Forest (Barros \& Callado 1997). However, some data on anatomical aspects are available in the literature for Myrsinoideae species, especially for the genus Stylogyne (Grose 1908; Otegui 1986; Carrijo et al. 2011).

Grose's monograph (1908) provides an overview of the anatomic traits in Myrsinoideae, in order to characterize the genera. More recent contributions have dealt with the description of the trichomes and crystals of Ardisia Sw. species (Lersten 1977), and the development of secretory cavities of Lysimachia nummularia L. (Lersten 1986). Other

\footnotetext{
Instituto de Pesquisas Jardim Botânico do Rio de Janeiro, R. Pacheco Leão 915, 22460-030, Rio de Janeiro, RJ, Brasil.

${ }^{2}$ Universidade Federal do Espírito Santo, Depto. Biologia, Alto Universitário s/nº 29500-000, Alegre, ES, Brasil.

${ }^{3}$ Corresponding author: brunaluna@jbrj.gov.br
} 
studies were conducted in order to clarify the limits among species within a genus. By the analysis of features such as venation, trichomes and stomata types, aspects of epidermis and cuticle, and the organization of vascular tissues in the petiole, Otegui (1998) was able to characterized related species of Myrsine L. The anatomical aspects of leaves, specifically epidermis and hydathodes, were also useful to delimit a new species from its related taxa (Carrijo et al. 2011). The wood anatomy also proved to be informative for Myrsinoideae systematics by the studies of Lens et al. (2005), in which wood anatomy was used to distinguished families.

Stylogyne depauperata Mez, S. pauciflora Mez, S. sordida Mez and S. warmingii Mez belong to the group of species with 4-merous flowers from Atlantic Rain Forest that is distinguishable by fine traits (see Carrijo et al. 2012). Differences among them are expressed mainly by leaf shape and size, which are attributes known to be influenced by the environment. Based on the premise that anatomy traits are potentially informative for Myrsinoideae systematics, the leaf anatomy of these species was analyzed in order to identify micromorphological characters useful to distinguish and delimited them.

\section{Material and Methods}

Fully expanded leaves from the third and fourth node were collected from three individuals of each species in different areas of Atlantic Rain Forest in Rio de Janeiro and Minas Gerais states, Brazil. Parque Estadual da Floresta da Tijuca $\left(22^{\circ} 25^{\prime}-23^{\circ} 01^{\prime} \mathrm{S}, 43^{\circ} 12^{\prime}-43^{\circ} 19^{\prime} \mathrm{W}\right)$ and Parque Estadual da Pedra Branca (22 $50^{\circ}-23^{\circ} 15^{\prime}$ S, 43 $20^{\circ}$ $\left.43^{\circ} 40^{\prime} \mathrm{W}\right)$ are located in Rio de Janeiro state. Parque Nacional da Serra dos Órgãos $\left(22^{\circ} 25^{\prime}-22^{\circ} 32^{\prime} \mathrm{S}\right.$, $\left.42^{\circ} 59^{\prime}-43^{\circ} 07^{\prime} \mathrm{W}\right)$ is located in Teresópolis, Rio de Janeiro state, and Fazenda Fortaleza is a private property in Divino, Carangola, Minas Gerais state. All sites are characterized as ombrophilous forest, according to Veloso et al. (1991) classification.
Collection data of studied material are included in the Herbarium RB (Tab. 1).

For light microscopy (LM), samples from the leaf blades, midribs and distal portion of petioles were fixed in an aqueous solution of $2.5 \%$ glutaraldehyde and $4.0 \%$ paraformaldehyde in 0.05 $\mathrm{M}$ cacodylate buffer at pH 7.2 (Klein et al. 2004) or in formalin-acetic acid-alcohol 70\% (FAA) (Johansen 1940) for 48 hours, and then dehydrated in a graded series of alcohol solution (10-100\%, 1 hour each). Subsequently, the samples were infiltrated and embedded in methacrylate resin. Transverse sections $(4 \mu \mathrm{m})$ were made using a rotatory microtome and were stained with toluidine blue (0.1\% aqueous solution) (Pearse 1968). The epidermis was dissociated using the solution of Franklin (1945) stained with 1\% safranin and mounted in glycerol $50 \%$. Histochemical tests were perfomed on fresh leaves sectioned by the freehand method. Hydrochloric phloroglucin was used to identify secondary lignified walls (Sass 1951), lugol to starch (Sass 1951), Sudan IV to lipophilic substances (Sass 1951), and ferric chloride to phenolic compounds (Johansen 1940). Leaf calcium oxalate crystals were tested by insolubility in acetic acid and solubility in hydrochloric acid (McLean \& Cook 1958). The images were obtained by using a digital camera Coolsnap attached to an Olympus BX50 microscope with the aid of the image analysis software Image Pro-Plus (4.0, version for Windows). For scanning electron microscopy (SEM), fragments of leaf blade were fixed in the same way as LM. After that, they were rinsed three times with the buffer and post-fixed for 1 hour with $1.0 \%$ osmium tetroxide in $0.05 \mathrm{M}$ cacodylate buffer at $\mathrm{pH} 7.2$ (Klein et al. 2004). The post-fixed samples were dehydrated in a cetonic series. Subsequently, they were criticalpoint-dried in $\mathrm{CO}_{2}$, sputter coated with $20 \mathrm{~nm}$ gold, and observed with a scanning electron microscope Zeiss EVO 40. The epidermal microcharacters (cuticular ornamentation, trichomes and stomata) were described following Metcalfe and Chalk (1979).

Table 1 - Species of Stylogyne studied and collection data

\begin{tabular}{|c|c|c|}
\hline Species & Collection data & $\begin{array}{l}\text { Collector, number } \\
\text { and herbarium }\end{array}$ \\
\hline Stylogyne depauperata $\mathrm{Mez}$ & Parque Nacional da Floresta da Tijuca $\left(22^{\circ} 25^{\prime}-23^{\circ} 01^{\prime} \mathrm{S}, 43^{\circ} 12^{\prime}-43^{\circ} 19^{\prime} \mathrm{W}\right)$ & T.T. Carrijo $1006-\mathrm{RB}$ \\
\hline Stylogyne pauciflora $\mathrm{Mez}$ & 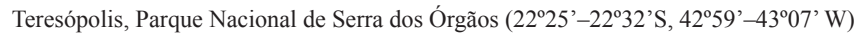 & T.T. Carrijo $289-\mathrm{RB}$ \\
\hline Stylogyne sellowiana $\mathrm{Mez}$ & Grumari, Parque Estadual da Pedra Branca $\left(22^{\circ} 50^{\prime}-23^{\circ} 15^{\prime} \mathrm{S}, 43^{\circ} 20^{\prime}-43^{\circ} 40^{\prime} \mathrm{W}\right)$ & T.T. Carrijo $136-\mathrm{RB}$ \\
\hline Stylogyne warmingii Mez & Divino, Carangola, Minas Gerais (MG). Fazenda Fortaleza & L. S. Leoni $6697-\mathrm{RB}$ \\
\hline
\end{tabular}


A binary matrix with the data obtained was done using absence (0) and presence (1). The matrix was subjected to cluster analysis using the Jaccard index as a measure of similarity and the unweighted arithmetic average clustering criterion (UPGMA) between sampling units. This analysis was performed on PAST. A factor analysis by principal components method (PCA) was also performed, which allowed the definition of the characteristics that most influenced the differentiation of species, influencing the spatial model produced. The PCA was performed with eight variables out of 14 . The other variables were excluded from analyses because they did not present variation nor had significant values. The eight variables used are: adaxial epidermis with striate surface, circular secretory structure, translucent secretory structure, abaxial epidermis with straight periclinal wall, abaxial epidermis with a convex periclinal wall, nigrescent secretory structure, secretory structures with projections through the mesophyll, brachysclereids in petiole.

\section{Results}

The petiole has a uniseriate epidermis, in cross section formed by small, packed, circular shaped cells. Under the epidermis, angular collenchyma formed by $5-6$ cell layers was found (Fig. 1a). Starch grains were detected in medulla and cortex (Fig. 1b), except in S. pauciflora where a starch sheath surrounding the vascular system was observed (Fig. 1c). Idioblasts containing calcium oxalate prismatic crystals or druses and secretory cavities were observed in the cortex (Fig. 1d). Secretory cavities are formed by epithelial cells filled with phenolic compounds; these cells are responsible for producing the secretion, which is stored in the lumen. The secretion has a brownish color and contains lipophilic compounds (Fig. 1e). In S. sordida, isolated or grouped brachysclereids distributed in the cortex were also visualized (Fig. 1g). The vascular system was formed by collateral vascular bundles. In $S$. sordida, they were arc-shaped (Fig. 1f), whereas in S. depauperata, S. warmingii, and S. pauciflora, "V" shaped with convoluted extremities (Fig. 1h). Phloroglucin histochemical test showed that at the distal portion the vascular system are formed by parenchymatic cells in S. pauciflora and $\mathrm{S}$. sordida (Fig. 1i), while in S. warmingii these sheaths are surrounded by sclerenchymatic fiber with thickened walls (Fig. 1j).
The leaf blade of all species, in frontal view presents an epidermis with isodiametric cells with wavy, thin anticlinal cell walls (Fig. 2a). Cross sections of leaf blades showed a uniseriated epidermis (Figs. 2b-c). The abaxial surface of $S$. pauciflora and S. sordida had cells with convex outer periclinal cell walls (Fig. 2b), whereas in $S$. depauperata and in $S$. warmingii they were straight (Fig. 2c). Anisocytic stomata were only found on the abaxial surface, at the same level as the other epidermal cells. There are peltate glandular trichomes on both epidermal surfaces, consisting of a basal cell, a short stalk cell, and a large multicellular head (Figs. 2d-e). On the abaxial surface of $S$. depauperata and S. pauciflora, the epidermal cells had a cuticular striation parallel to the longest axis of the cell. In S. sordida striations were small, less evident, and were restricted to the periphery of the epidermal cells (Figs. 2fg). Around the stomata, there are epicuticular ornamentations forming concentric rings, being more numerous in $S$. depauperata, $S$. warmingii, and S. pauciflora. Surrounding the trichomes, epidermal cells were radially arranged in all species. In all species the mesophyll was dorsiventral (Fig. 3a). Parenchymatic tissue situated near the adaxial epidermis presented small cells with invaginations, characterizing a plicade parenchyma (Fig. 3b). The spongy parenchyma was composed of about six cell layers. In all species, cells in this tissue had different proportions, producing intercellular spaces of different sizes. There were secretory cavities distributed throughout the mesophyll (Fig. 3c). In frontal view, these structures can be elongated or round, and were composed of an epithelial cell layer, bordering a lumen (Fig. $3 d)$. Epithelial cells were elongate and formed a branched structure in $S$. warmingii (Fig. 3e-f). As in the petiole, the secretion is composed of lipophilic and phenolic substances. In fresh leaves, this secretion was translucent, whereas in fixed leaves it had a yellowish color. The only exception is $S$. warmingii, where it was nigrescent in fresh leaves. The presence of idioblasts of druse calcium oxalate crystals in the parenchymatic tissues of the leaf blade is a common character of all analyzed species (Fig. 3g).

Data analysis generated from the binary matrix of presence and absence (Tab. 2) showed the potential value of the anatomical characters to separate the studied species, as is observed in UPGMA cluster analysis, which divided the four 

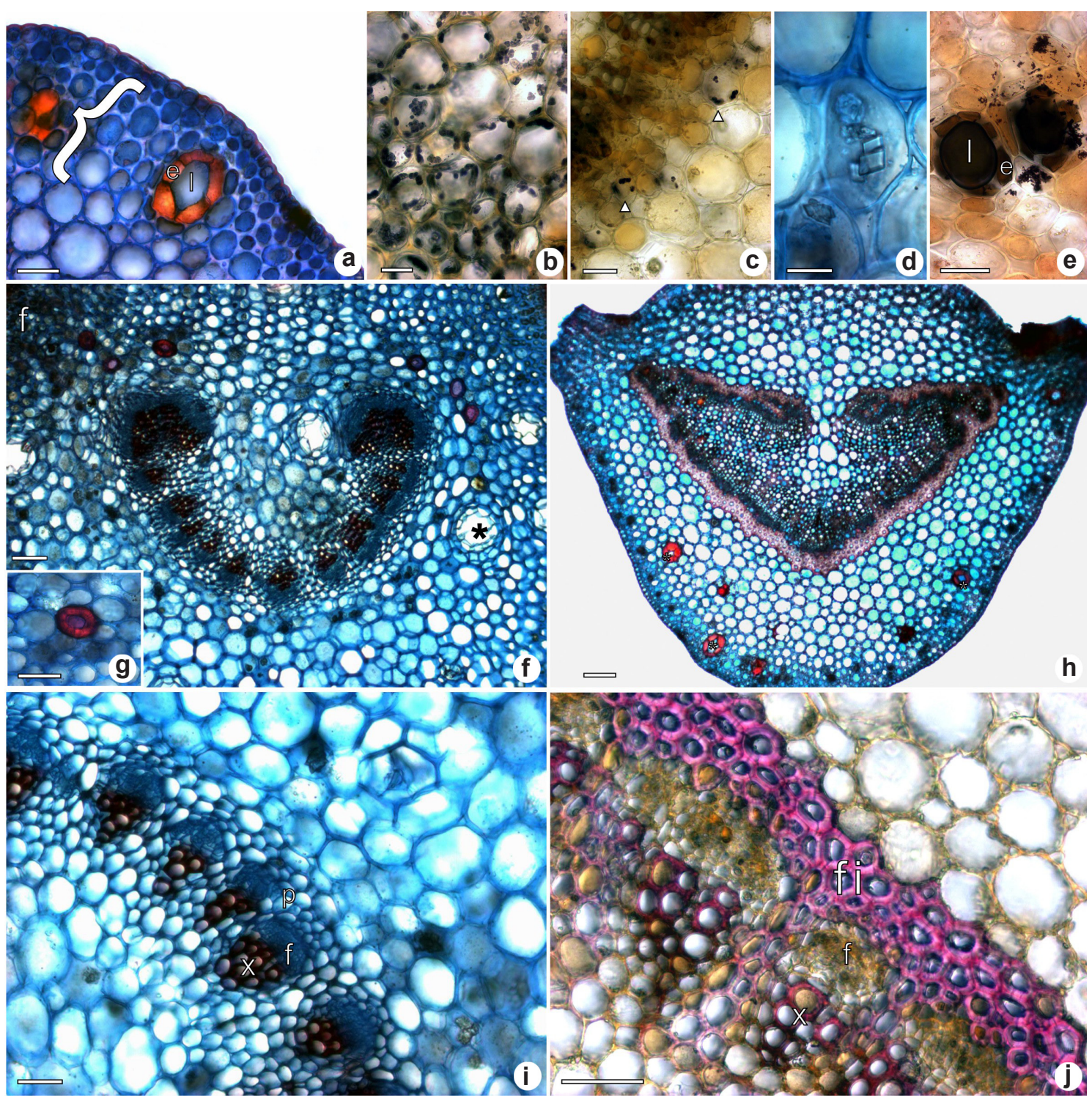

Figure 1 - Anatomical aspects of Stylogyne petioles - a. layers of collenchyma and secretory cavity in S. warmingii cortex, (e) - epithelial cell, (1) - lumen. Bar $=20 \mu \mathrm{m}$. b, c. starch grains in amiloplasts in the cortex of S. sordida and S. pauciflora, respectively. Bar $=50 \mu \mathrm{m}$. d. prismatic crystals in $S$. sordida. Bar $=50 \mu \mathrm{m}$. e. secretory cavity, with the secretory content in the lumen (1) surrounded by epithelial cells (e) in $S$. sordida cortex. Bar $=100 \mu \mathrm{m}$. f. vascular system arc-shaped in $S$. sordida petiole. Bar $=100 \mu \mathrm{m}$. g. brachysclereids in S. sordida. Bar $=100 \mu \mathrm{m}$. h. vascular system with a "V" configuration in $S$. warmingii, $\left(^{*}\right)$ - secretory cavities. Bar $=100 \mu \mathrm{m}$. i. vascular system in $S$. sordida, with parenchymatic sheath cells (p) and j. in S. warmingii with sclerenchymatic sheath cells (fi); (x) - xylem, (f) - phloem. Bar $=50 \mu \mathrm{m}$.

Stylogyne species in three groups (Fig. 4). The first group was formed by $S$. depauperata, S. pauciflora, and $S$. sordida because of the translucent cylindrical or round secretory cavities in the mesophyll. The second group included $S$. sordida and $S$. pauciflora which presented an abaxial epidermis with convex periclinal walls in cross section. The third group included $S$. warmingii, because of its internal nigrescent branched secretory cavities (Fig. 4). Factor analyses by principal components indicated that the features that influenced the species bidimensional distribution explaining $85 \%$ of variation were: adaxial epidermis with striated surface, round secretory cavities, branched 


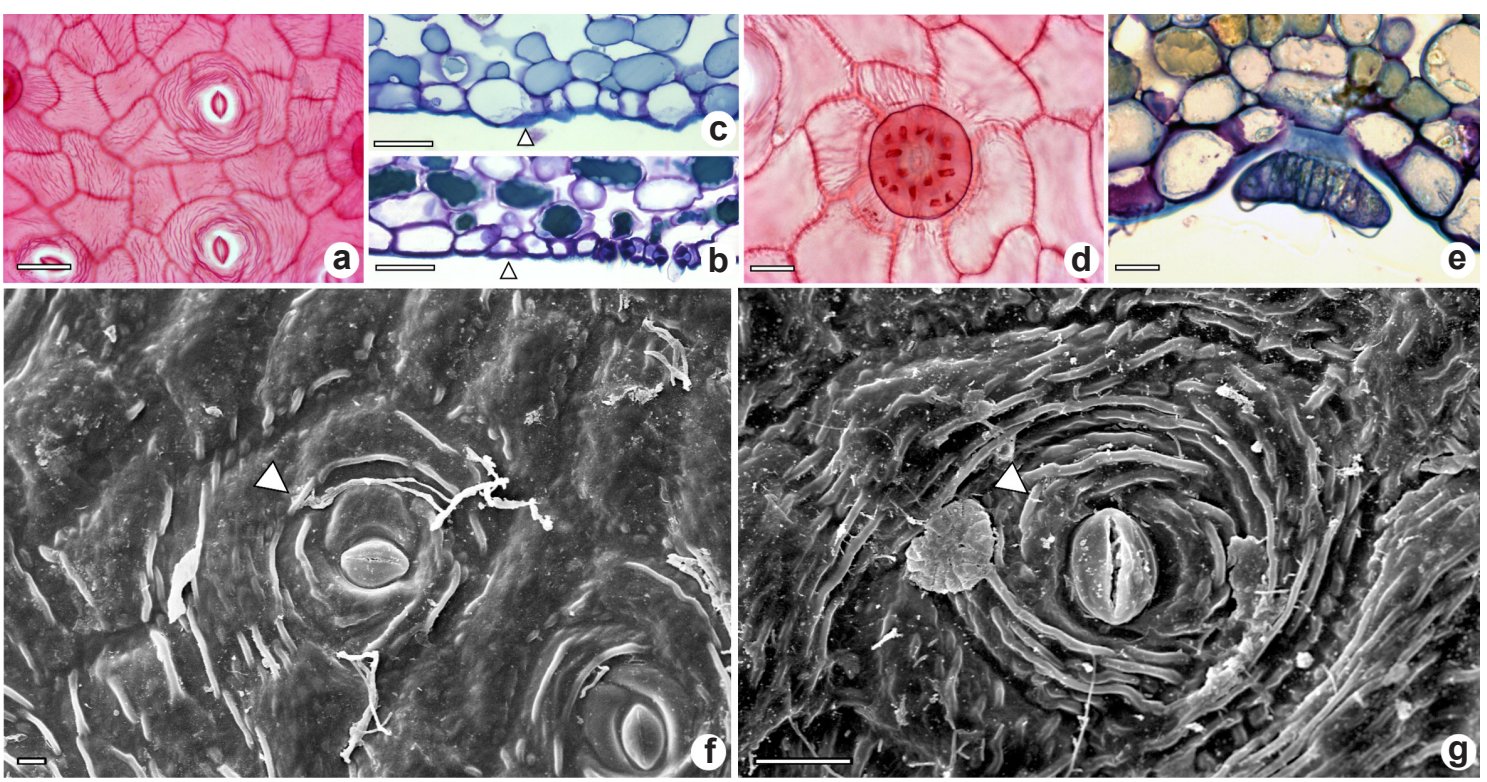

Figure 2 - Epidermal aspects of Stylogyne species - a. frontal view of S. warmingii abaxial epidermis, with anisocytic stomata. Bar $=50 \mu \mathrm{m}$. b, c. transverse section of $S$. sordida and $S$. depauperata leaves, respectively. Bar $=50 \mu \mathrm{m}$. b. convex outer periclinal cell walls in the abaxial epidermis. c. straight outer periclinal cell walls in the abaxial epidermis. d, e. frontal view and cross section, respectively, of the peltate trichomes in $S$. warmingii. f, g. frontal view of $S$. sordida and $S$. depauperata, respectively, leaves under scanning electron microscopy, showing cuticle ornamentation. Bars $=10 \mu \mathrm{m}, 20 \mu \mathrm{m}$, respectively.

secretory cavities, translucent secretion, nigrescet secretion, abaxial epidermis with straight external periclinal wall, wavy external periclinal wall and isolated sclerenchymatic cells in petiole (Fig. 5).

\section{Discussion}

All studied species have an anatomical pattern close to that reported for other Myrsinoideae (Metcalfe \& Chalk 1979; Otegui \& Maldonado 1998; Gostin et al. 2011), as the unistratified epidermis with anisocytic stomata placed at the same level of the other cells of this tissue, dorsiventral mesophyll with secretory cavities, and idioblasts containing calcium oxalate crystals.

Although the mesophyll is strongly influenced by environmental variation such as light availability (Rôças et al. 1997, 2001), Stylogyne species have a dorsiventral mesophyll, formed by plicade cells near the adaxial epidermis. This feature seems to be properly of the genus, being a distinctive character from other Myrsinoideae genera, where it is common to observe the mesophyll formed by common palisade cells (Otegui \& Maldonado 1998; Pipoly 1998).

Among Myrsinoideae species, different types of secretory tissues can be found, such as glandular trichomes, secretory cavities, and hydathodes (Grosse 1908; Solereder 1908; Metcalf \&Chalk 1950; Lersten 1977). In Stylogyne, secretory cavities and peltate glandular trichomes are found and are described here for the first time. The general characteristic of secretory tissues, such as micromorphology and localization, has been used by many authors in other families as useful features to taxonomy, as in Lonchocarpus Kunth - Fabaceae (Teixeira et al. 2000), in Pilocarpus Vahl - Rutaceae (Muntoreanu et al. 2011), where the authors pointed out the secretory cavities as distinctive characters for species segregation, and in Stachys L.- Lamiaceae (Salmaki et al. 2009) where trichome aspects were useful to segregate species within the genus.

In Myrsinoideae, trichome characteristics have been used by Otegui and Maldonado (1998) where types of trichomes were useful to classify Myrsine species, by Fico et al (2007), where trichome types were identified and described to discriminate three Primula L. species. Although in Stylogyne only one type of trichome, the peltate type with a multicellular head, was found, being of no taxonomic utility within the genus, it is a valuable trait considering the family as a whole. 


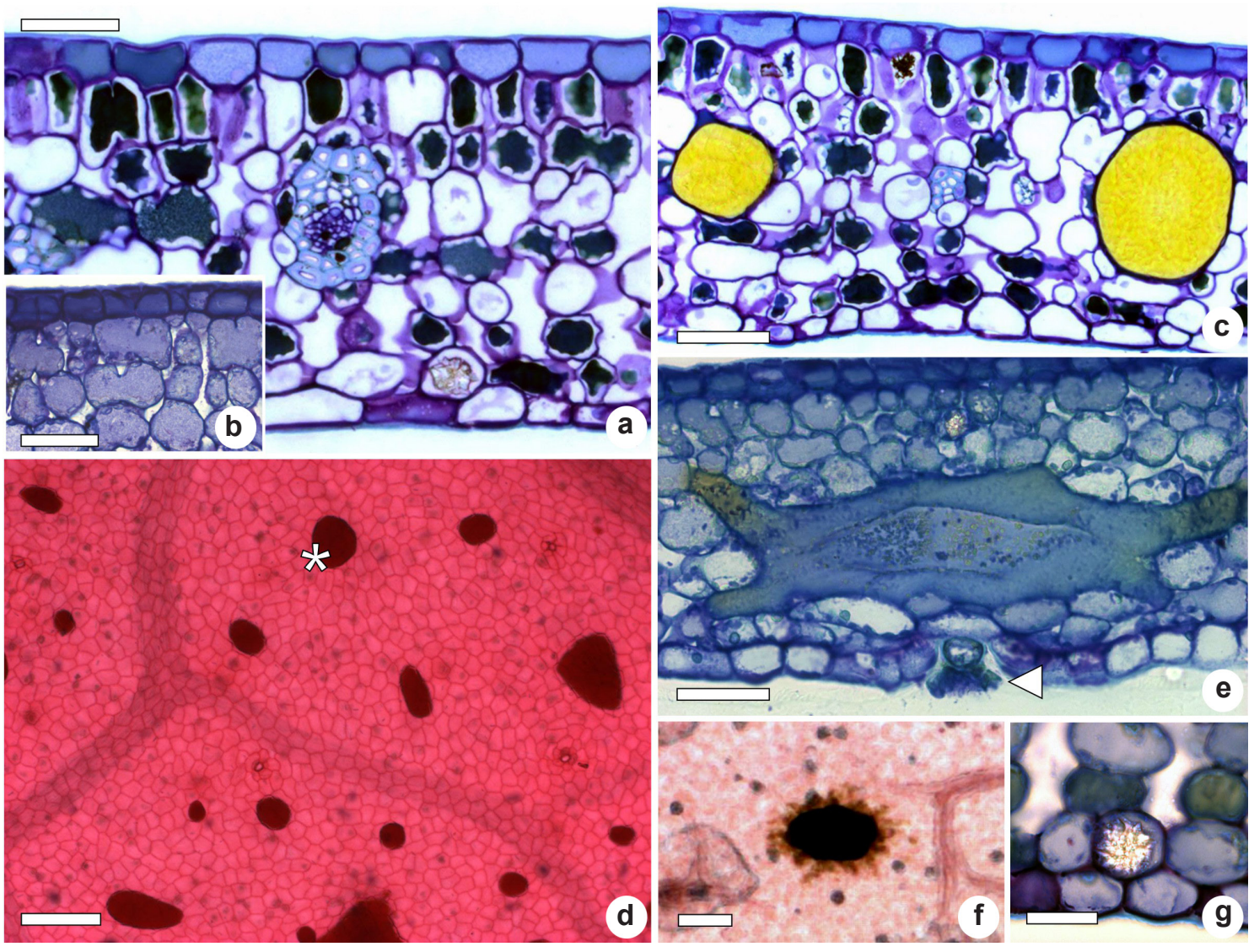

Figure 3 - Mesophyll anatomical aspects of Stylogyne - a. cross section of S. depauperata leaf, showing the dorsiventral mesophyll and the unistratified epidermis. Bar $=50 \mu \mathrm{m}$. b. plicade parenchyma in the mesophyll of S. warmingii. Bar $=20 \mu \mathrm{m}$. c, d. secretory cavities with lipophilic content in $S$. depauperata mesophyll, c. in cross section and d. in frontal view (*). Bar $=50 \mu \mathrm{m}$. e. cross section of $S$. warmingii leaf, showing the branched secretory structure in the mesophyll. Bar $=50 \mu \mathrm{m}$. f. frontal view of the branched secretory structure in S. warmingii. Bar $=100 \mu \mathrm{m}$. g. druse shaped crystal in $S$. warmingii mesophyll. Bar $=20 \mu \mathrm{m}$.

Table 2 - Presence (1) and absence (0) matrix of four Stylogyne species. FV - Frontal view; TS - transverse section.

\begin{tabular}{|c|c|c|c|c|}
\hline & S. depauperata & S. sordida & S. pauciflora & S. warmingii \\
\hline Epidermal cells with wavy anticlinal walls in the abaxial surface - FV & 1 & 0 & 0 & 1 \\
\hline Epidermal cells with wavy periclinal walls in the abaxial surface - TS & 0 & 1 & 1 & 0 \\
\hline Epidermal cells with straight periclinal walls in the abaxial surface - TS & 1 & 0 & 0 & 1 \\
\hline Adaxial epidermis with striated surface $-\mathrm{FV}$ & 1 & 0 & 1 & 1 \\
\hline Secretory cavities round shaped or elongated in the mesophyll & 1 & 1 & 1 & 0 \\
\hline Branched secretory cavities in the mesophyll & 0 & 0 & 0 & 1 \\
\hline Nigrescent secretory cavities in the mesophyll & 0 & 0 & 0 & 1 \\
\hline Transluscent secretory cavities in the mesophyll & 1 & 1 & 1 & 0 \\
\hline Brachysclereids in the petiole & 1 & 1 & 0 & 0 \\
\hline Vascular system arranged in arc shape in the petiole & 0 & 1 & 1 & 0 \\
\hline Vascular system arranged in a "V" shape in the petiole & 1 & 0 & 0 & 1 \\
\hline
\end{tabular}




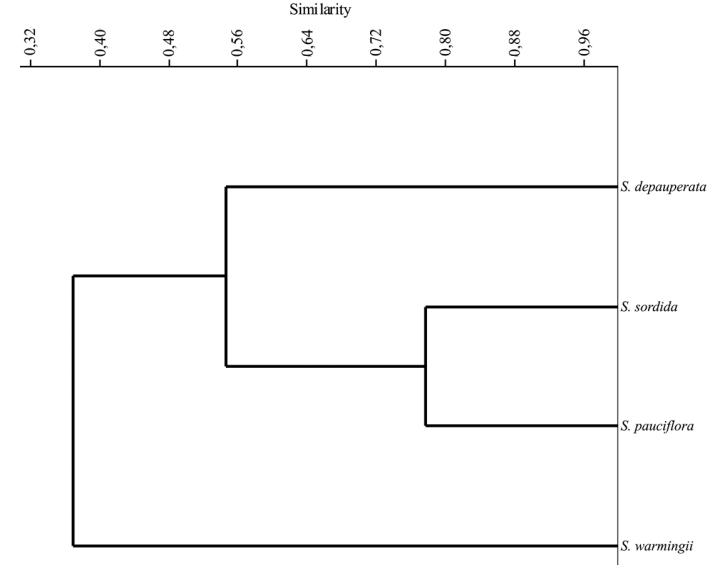

Figure 4-UPGMA analysis from Stylogyne studied species.

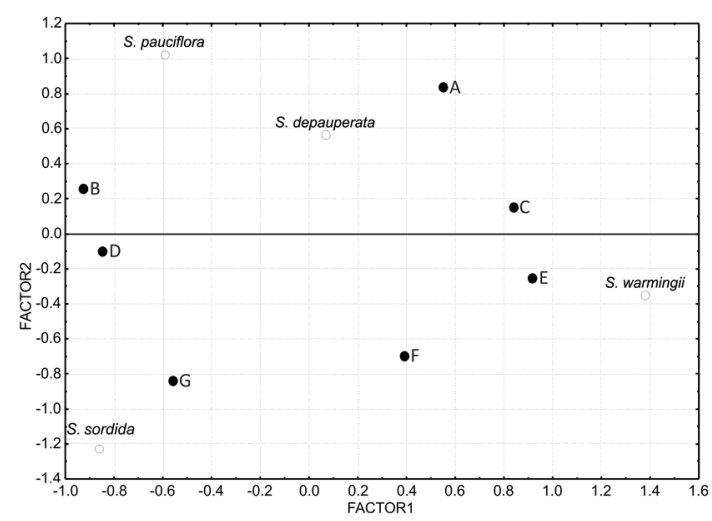

Figure 5 - Biplot principal component analysis (PCA). A: adaxial epidermis with striated surface, B: translucent circular shaped secretory cavities, $\mathrm{C}$ : thin wall abaxial epidermis, D: wavy wall abaxial epidermis, E: nigrescent branched secretory cavities, F: isolated sclerenchymatic cells in petiole.

Secretory cavities are an outstanding trait in Primulaceae (Judd et al. 2009; Stevens 2001 onwards). They are used, among other features, to segregate the clade formed by Lysimachia L., Myrsine L., and Primula L. into two sub-families: Primuloideae, which is composed of species without secretory cavities, and Myrsinoideae, including species with these cavities (Judd et al 2009). These structures are visible in the leaves as translucent punctuations (Carrijo \& Freitas 2008). Among the analyzed Stylogyne species, only $S$. warmingii does not present translucent punctuations in leaves. In cross section, secretory cavities have a well delimited shape in all species, except in $S$. warmingii, where they are branched.
Chemical composition of the secretion from secretory cavities is known in Ardisia Sw., Aegiceras Gaertn., Embelia Burm. f., Myrsine and Tapeinosperma Hook f., where hidroxybenzoquinone derivates and lipophilic substances have been reported. (Tuntiwachwuttikulo et al. 1997; Otegui et al. 1998). This secretion is associated with different pharmacological activities, such as antioxidant (Sumino et al. 2002), antihelminthic (Challam et al. 2010) and antileishmania (Germonprez et al. 2004; Vermeesch et al. 2009). Histochemical test results here performed confirmed the lipophilic composition of the secretion in Stylogyne, but further analyses about the nature of this composition are needed.

Cuticular ornamentation is one of the most informative taxonomic features of epidermis in leaves (e.g. Solereder 1908; Metcalfe \& Chalk 1979; Barthlott et al. 1998), and has been used in species identification, for example in Trifolium L.- Fabaceae (Zoric et al. 2009) and Posoqueria Aubl.- Rubiaceae (Arruda et al. 2010). All Stylogyne species have a striate epidermis. In $S$. depauperata, $S$. pauciflora, and $S$. warmingii the epidermis is very striated while in $S$. sordida they are few confined to the periphery. Further analysis of the cuticular relief in other Stylogyne species has potential to provide attributes for genus taxonomy.

The presence of brachysclereids in the petiole was also an efficient character to distinguish Stylogyne species. The presence or absence and the distribution of this feature in the plant organ has been used by some authors to segregate closely related species, as is shown, for example, in the comparative leaf anatomy of Macropeplus dentatus (Perkins) I. Santos \& Peixoto and M. ligustrinus (Tul.) Perkins (Costa et al. 2010) and in some species of Mirabilis L. (Nyctaginaceae) (Hernández-Ledesma et al. 2011). Besides the taxonomic importance of brachysclereids, Haberlandt (1928) associates this feature with increased organ resistance.

Another relevant trait of species characterization and differentiation is the organization of the vascular system in the petiole (Fahn 1990). While in S. sordida and S. warmingii it is "V" shaped, in S. pauciflora it is arc shaped. Some of these features have been identified in other groups, where they were proved to be useful for taxonomy, as in Campomanesia - Myrtaceae (Oliveira et al. 2011), Rubiaceae (Martínez-Cabrera 2009) and in Melastomataceae (Reis et al. 2004) in which the distinctive characters were, among others, the vascular system pattern in the petiole. 
UPGMA clustering analyzis and PCA analyses reinforced the value of the anatomical features for species segregation. Anatomical traits that contributed to this conclusion were: shape of secretory cavities in mesophyll, ornamentation of abaxial epidermis, presence of isolated brachisclereids in petiole and the shape of epidermal cells in cross section. Anatomical aspects from all studied species showed a pattern, indicating that they can be grouped in the same genus. Besides, the micromorphological variation was also proved to be efficient for species segregation, as was shown by UPGMA analysis.

\section{Aknowlegdments}

We thank PIBIC (CNPq) for scholarship support. To FAPERJ, Petrobras and Probio II for financial support. And to G. Bernadello, D.E. Klein, and R.C.O. Arruda for their critical reading of the manuscript.

\section{References}

Arruda, R.C.O.; Gomes, D.M.S.; Magalhães, M.L.; Azevedo, A.C. \& Gomes, M. 2010. Leaf anatomy and micromorphology of six Posoqueria Aublet species (Rubiaceae). Rodriguésia 61: 505-518.

Anderberg, A.A. \& Stahl, B. 1995. Phylogenetic interrelationships in the Order Primulales, with special emphasis on the family circumscriptions. Canadian Journal of Botany 73: 1699-1730.

Barros, C.F. \& Callado, C.H. 1997. Madeiras da Mata Atlântica: anatomia do lenho de espécies ocorrentes nos remanescentes florestais do estado do Rio de Janeiro - Brasil. Vol.1. Jardim Botânico do Rio de Janeiro, Rio de Janeiro. 86p.

Barthlott, W.; Neinhuis, C.; Cutler, D.; Ditsch, F.; Meusel, I.; Theisen, I. \& Wilhelmi, H. 1998. Classification and terminology of plant epicuticular waxes. Botanical Journal of the Linnean Society 126: 227-236.

Bernacci, L.C. \& Jung-Mendaçolli, S.L. 2000. Considerações taxonômicas e novas combinações em Ardisia Swartz (Myrsinaceae) do sudeste do Brasil. Acta Botanica Brasilica 14: 243-249.

Câmara, I.G. 2003. Brief history of conservation in the Atlantic Forest. In: Galindo-Leal C. \& Câmara I. G. (eds.). The Atlantic Forest of South America: biodiversity status, threats and outlook. CABS and Island Press, Washington. Pp. 31-42.

Carrijo, T.T \& Freitas, M.F. 2008. Stylogyne (Myrsinaceae) no estado do Rio de Janeiro, Brasil. Rodriguésia 59: 343-360.

Carrijo, T.T \& Freitas, M.F. 2009. Stylogyne carautae (Myrsinaceae) a new species from southeastern Brazil. Kew Bulletin 64: 695-699.
Carrijo, T.T. 2011. Revisão taxonômica das espécies de Stylogyne A. DC. (Myrsinoideae-Primulaceae) do Brasil. Tese de Doutorado. Instituto de Pesquisas Jardim Botânico do Rio de Janeiro, Escola Nacional de Botânica Tropical, Rio de Janeiro. 353f.

Carrijo, T.T.; Freitas, M.F. \& Peixoto, A.L. 2012. The genus Stylogyne (Myrsinoideae-Primulaceae) in Brasil. Systematic Botany 37: 478-489.

Challam, M.; Roy, B. \& Tandon, V. 2010. Effect of Lysimachia ramosa (Primulaceae) on helminth parasites: motility, mortality and scanning electron microscopic observations on surface topography. Veterinary Parasitology 169: 214-218.

Costa, F.F.; Lima, H.R.P.; Da Cunha, M. \& Santos, I.S. 2010. Leaf anatomy and histochemistry of Macropeplus dentatus (Perkins) I . Santos \& Peixoto and Macropeplus ligustrinus (Tul.). Acta Botanica Brasilica 24: 852-861.

Cronquist, A. 1981. An integrated system of classification of the dicotyledons. Columbia University Press, New York. 1262p.

Cronquist, A. 1988. Evolution and classification of flowering plants. $2^{\text {nd }}$ ed. The New York Botanical Garden. 556p.

Cutter, E. 2002. Anatomia vegetal (Parte II). $2^{\mathrm{a}}$ ed. Roca, São Paulo. 336p.

Diane, N.; Jacob, C. \& Hilger, H.H. 2003. Leaf anatomy and foliar trichomes in Heliotropiaceae and their systematic relevance. Flora 198: 468-485.

Esau, K. 1977. Anatomy of seed plants. John Wiley \& Sons, New York. 550p.

Fahn, A. 1990. Plant anatomy. Pergamon Press, Oxford. $588 \mathrm{p}$.

Feder, N \& O’Brien, T.P. 1968. Plant microtechnique: some pinciples and new methods. American Journal of Botany 55: 123-142.

Fico, G.; Rodondi, G.; Flamini, G.; Passarella, D. \& Tomé, F. 2007. Comparative phytochemical and morphological analyses of three italian Primula species. Phytochemistry 68: 1683-1691.

Franklin, G. 1945. Preparation of thin sections of synthetic resins and wood-resin composites and a new macerating method for wood. Nature 155: 51.

Freitas, M.F. \& Carrijo, T.T. 2008. A família Myrsinaceae nos contrafortes do maciço da Tijuca de entorno do Jardim Botânico do Rio de Janeiro, Brasil. Rodriguésia 59: 813-828.

Germonprez, N.; Van Puyvelde, L.; Maes, L.; Van Tri, M. \& De Kimpe, N. 2004. New pentacyclic triterpene saponins with strong anti-leishmanial activity from the leaves of Maesa balansae. Tetrahedron 60: 219-228.

Guedes - Bruni R.R.; Pessoa, S.V.A. \& Kurtz, B.C. 1997. Florística e estrutura do componente arbustivo-arbóreo de um trecho preservado de floresta montana na Reserva Ecológica de Macaé de 
Cima. In: Lima, H.C. \& Guedes-Bruni, R.R. (eds.). Serra de Macaé de Cima: diversidade florística e conservação em Mata Atlântica. Instituto de Pesquisas do Jardim Botânico do Rio de Janeiro, Rio de Janeiro. Pp. 125-145.

Gostin I.N.; Zamfirache, M.M. \& Ştefan M. 2011. Anatomical and micromorphological aspects at Ardisia crenata Sims. Analele ştiințifice ale Universităţii “Alexandru Ioan Cuza" din Iaşi Biologie vegetală 57: 5-12.

Grosse, A. 1908. Anatomisch-systematische Untersuchungen der Myrsinaceen. Botanische Jahrbücher für Systematik 41: 1-46.

Haberlandt, G. 1928. Physiological plant anatomy. MacMillan, London. 777p.

Hernández-Ledesma, P.; Terrazas, T. \& Flores-Olveras, H. 2011. Comparative stem anatomy of Mirabilis (Nyctaginaceae). Plant Systematics and Evolution 292: 117-132.

Johansen, D. 1940. Plant microtechnique. McGraw- Hill, New York. 523p.

Judd, W.S.; Campbell, C.S.; Kellog, E.A., Stevens, P.F., Donoghue, M.J. 2009. Sistemática vegetal - um enfoque filogenético. $3^{\mathrm{a}} \mathrm{ed}$. Artmed, Porto Alegre. $623 p$.

Jung-Mendaçolli, S.L. \& Bernacci, L. C. 2001. Myrsinaceae da APA de Cairuçu, Parati (Rio de Janeiro, Brasil). Rodriguésia 52: 49-64.

Karnovsky, M.J. 1965. A formaldehyde-glutaraldehyde fixative of high osmolality for use in eletron microscopy. Journal of Cellular Biology 27: 137-138.

Klein, D.E.; Gomes, V. M.; Silva-Neto, S.J. \& da Cunha, M. 2004. The structure of colleters in several species of Simira (Rubiaceae). Annals of Botany 94: 733-740.

Kraus, J.E. \& Arduim, M. 1997. Manual básico de métodos em morfologia vegetal. Ed. Universidade Rural, Seropédica.198p.

Lens, F.; Jansen, S.; Caris, P.; Serlet, L. \& Smets, E. 2005. Comparative wood anatomy of the Primuloid Clade (Ericales s.1.). Systematic Botany 30: 163-183.

Lersten, N.R. 1977. Trichome forms in Ardisia (Myrsinaceae) in relation to the bacterial leaf nodule symbiosis. Botanical Journal of the Linnean Society 75: 229-244.

Lersten, N.R. 1986. Re-investigation of secretory cavity development in Lysimachia (Primulaceae). New Phytologist 102: 193-197.

Lima, H.C. \& Guedes-Bruni, R.R. (eds.). 1997. Serra de Macaé de Cima: diversidade florística e conservação em Mata Atlântica. Jardim Botânico do Rio de Janeiro, Rio de Janeiro. 345p.

Martínez-Cabrera, D.; Terrazas, T. \& Ochoterena, H. 2009. Foliar and petiole anatomy of Tribe Hamelieae and other Rubiaceae. Annals of the Missouri Botanical Garden 96: 133-145.
Matias, L.Q.; Soares, A. \& Scatena, V.L. 2007. Systematic consideration of petiole anatomy of species of Echinodorus Richard (Alismataceae) from north-eastern Brazil. Flora 202: 395-402.

McLean R.C. \& Cook W.R.I. 1958. Plant science formulae. MacMillan, London. 203p.

Metcalfe, C.R. \& Chalk. 1950. Anatomy of the dicotyledons. Vol. II. Oxford Claredon Press, Oxford. 1500p.

Metcalfe, C.R. \& Chalk, L. 1979. Anatomy of dicotyledons. Vol. I: Systematic anatomy of the leaf and stem with a brief history of the subject, $2^{\text {nd }}$ ed. Oxford University Press, Oxford. Pp. 47-51.

Mez, C. 1902. Myrsinaceae. In: Engler, H.G.A. (ed.). Das Pflanzenreich. Vol. 9. Wilhelm Eengelmann, Berlin. Pp. 1-437.

Muntereanu, T.G.; Cruz, R.S. \& Melo-de-Pina, G.F. 2011. Comparative leaf anatomy and morphology of some neotropical Rutaceae: Pilocarpus Vahl and related genera. Plant Systematic and Evolution 296: 87-99.

Oliveira, M.I.U.; Funch, L.S.; Ribeiro dos Santos, F.A. \& Landrum, L.R. 2011. Aplicação de caracteres morfoanatômicos foliares na taxonomia de Campomanesia Ruiz \& Pavon (Myrtaceae). Acta Botanica Brasilica 25: 455-465.

Otegui, M. 1998. Sinopsis del género Myrsine (Myrsinaceae) en el cono sur de América del Sur. Candollea 53: 133-157.

Otegui, M. \& Maldonado, S. 1998. Morfologia foliar de las especies de Myrsine L. (Myrsinaceae) del Cono Sur de America del Sur. Candollea 53: 349-363.

Pearse. A.G.E. 1968. Histochemistry - theoretical and applied. Vol. I. J. \& A. Churchill, London. 759p.

Pessoa, S.V.A.; Guedes-Bruni, R.R. \& Kurtz, B.C. 1997. Composição florística e estrutura do componente arbustivo/arbóreo de um trecho secundário de floresta montana na Reserva Ecológica de Macaé de Cima. In: Lima, H.C. \& Guedes-Bruni, R.R. (eds.). Serra de Macaé de Cima: diversidade florística e conservação em mata atlântica. Instituto de Pesquisas Jardim Botânico do Rio de Janeiro, Rio de Janeiro. Pp. 147-167.

Pinheiro, A.L. \& Carmo, A.P.T. 1993. Contribuição ao estudo tecnológico da canela-azeitona, Rapanea ferruginea (Ruiz e Pav.) Mez, uma espécie pioneira. I. Características anatômicas da madeira. Ciência Florestal 1: 121-125.

Pipoly, J.J. 1998. The genus Cybianthus (Myrsinaceae) in Ecuador and Peru. Sida 18: 1-60.

Purvis, M.J.; Collier, D.C. \& Walls, D. 1964. Laboratory techniques in botany. Butterwoths, London. 371p.

Reis, C.; Proença S.L. \& Sajo M.G. 2004. Vascularização foliar e anatomia do pecíolo de Melastomataceae do cerrado do estado de São Paulo, Brasil. Acta Botanica Brasilica 18: 987-999. 
Rôças, G.C.F.; Barros, C.F. \& Scarano, F.R. 1997. Leaf anatomy plasticity of Alchornea triplinervia (Euphorbiaceae) under distinct light regimes in a brazilian montane Atlantic Rain Forest. Trees 11: 469-473.

Rôças, G.; Scarano, F.R. \& Barros, C. F. 2001. Leaf anatomical variation in Alchornea triplinervia (Spreng.) Müll. Arg. (Euphorbiaceae) under distinct light and soil water regimes. Botanical Journal of the Linnean Society 136: 1-8.

Ricketson, J.M. \& Pipoly, J.J. 1997. Nomenclatural notes and a synopsis of Mesoamerican Stylogyne (Myrsinaceae). Sida 17: 591-597.

Ricketson, J.M. \& Pipoly III, J.J. 2009. Two new species of Stylogyne (Myrsinaceae) from Brazil. Novon 19: 497-501.

Salmaki, Sh.; Zarre, Z.; Jamzad, C. \& Bräuchler. 2009. Trichome micromorphology of Iranian Stachys (Lamiaceae) with emphasis on its systematic implication. Flora 204: 371-381.

Sass, J.E. 1958. Elements of botanical microthecnique. McGraw-Hill, New York, London. 222p.

Ståhl, B. \& Anderberg, A.A. 2004. Myrsinaceae. In: Kubtski, K. (ed.). The families and genera of vascular plants - VI. Flowering plants dicotyledons. Celastrales, Oxalidales, Rosales, Cornales, Ericales. Springer, Berlin. Pp. 266-281.

Stevens, P.F. (2001 onwards). Angiosperm Phylogeny Website. Version 12, July 2012 [and more or less continuously updated since] Smith, F.H.; Smith, E.C. 1942. Anatomy of the inferior ovary of Darbya. American Journal of Botany 29: 464-471.
Solereder, H. 1908. Systematic anatomy of dicotyledons. A handbook for laboratories of pure applied Botany. 2. vols. Clarendon Press, Oxford. 1182p.

Sumino, M.; Sekine, T.; Ruangrungsi, N.; Igarashi K. \& Ikegami, F. 2002. Ardisiphenols and other antioxidant principles from the fruits of Ardisia colorata. Chemical Pharmacological Bulletin 50: 1484-1487.

Teixeira, S.P.; Castro M.M. \& Tozzi. A.M.G.A. 2000. Secretory cavities and pellucid dots in leaflets of Lonchocarpus (Leguminosae, Papilionoideae, Millettieae). Plant Systematics and Evolution 221: 61-68.

Tuntiwachwuttikul, P.; Pancharoen, O.; Mahabusarakam, W.; Wiriyachitra, P.; Walter C.; Taylor, W.C.; Bubb, W.A. \& Towers, G.H.N. 1997. A Triterpenoid saponin from Maesa Ramentacea. Phytochemistry 44: 491-495.

Veloso, R.B.; Rangel Filho, A.L.R. \& Lima, J.C.A. 1991. Classificação da vegetação brasileira, adaptada a um sistema universal. IBGE, Rio de Janeiro. 123p

Vermeesch, M.; Foubert, K.; Luz, R.I.; Puyvelde, L.V.; Piters, L.; Cos, P. \& Mães, L. 2009. Selective antileishmania activity of 13,28-epoxy-oleanane and related triterpene saponins from the plant families Myrsinaceae, Primulaceae, Aceraceae e Icacinaceae. Phytotherapy Research 23: 1404-14.

Zoric, L.; Merkulov, L.; Lukovic, J.; Boza, P. \& Polic, D. 2009. Leaf epidermal characteristics of Trifolium L. species from Serbia and Montenegro. Flora 204: 198-209. 